\title{
他者強化の学習に及ぼす効果
}

\author{
一年齢差の検討一 \\ 小川亮*・根 建 金 男**・春木 豊***

\section{A DEVELOPMENTAL STUDY OF THE EFFECTS OF ALIEN REINFORCEMENT}

Ryo Ogawa, Kaneo NedATe AND Yutaka HaRUKI

\begin{abstract}
The present study examined the effects of a new mode of reinforcement, the 'Alien' mode of Reinforcement (AR), as compared to a External one (ER) and a double reinforcement (EAR). In Exp. I, 60 children and 30 adolescents were asked to perform high discrimination tasks under either of the 3 conditions mentioned above. Subjects were 3rd and 6th graders in a primary school and 3rd graders in a junior high school. In Exp. II, under the same 3 conditions as in Exp. I, a task of choosing one among four given words was administered to 72 adolescents belonging to 2 nd grade in junior (J2) and senior high (H2) schools. While fairly stable effects were found in ER and EAR conditions, no significant effects of AR condition on learning were found except in $\mathrm{H} 2$ group of Exp. II. Taking account of the findings of Haruki, et al. (1979), AR seems to become fully effective, in developmental phase, somewhere between senior high school and university.
\end{abstract}

Key words: children, adolescents, alien reinforcement, modes of reinforcement, social behavior theory.

人間の学習は, 動物の学習事態とは異なって, 常に, 教師と生徒, セラピストとクライエント,コーチと選 手, 親方と弟子, 課長と課員, 親と子といった人間関係 の中で生じている現象であるということを考虑する必要 がある。

春木 (1978) はこのような考えにもとゔき, 教授者 (制御者) と学習者 (被制御者) との間で行われる学習 あるいは行動制御は 4 つの強化のモードとその組合わせ によっていると仮説した。この場合, 強化とは二者の間 で強化子が発動され受理されることであり, 強化子を管 理し発動する者とそれを受理し享受する者とが，教授者 であるか学習者であるかによって，4 種の強化のモード

(外的強化 - 自己強化 - 内的強化 - 他者強化の各モ-

ド）が仮説できるとしている。****

(1)外的強化とは伝統的な行動理論でいわれてきた強化

* 早稲田大学大学院 (Waseda University)

** 広島大学総合科学部 (Hiroshima University)

*** 早稲田大学 (Waseda University)
モードである。強化子注境側, この場合には教授者が 管理し，学習者が受理する。その結果，教授者が意図し ている行動を学習者がするようになる。(2)自己強化は強 化子の管理は学習者自身であり受理も学習者である場合 である。この強化のモードについては既に実験的研究が

**** 4 つの強化モードに関する用語には, 漢語・和語 ・英語の 3 通りがあり，次のような対応関倸にある。 漢語和語英語略語 外的強化「おしつけ」強化 External Reinforcement ER 自己強化「まかせ」強化 Self Reinforcement SR 内的強化「うけとめ」強化 Internal Reinforcement IR 他者強化「みとめ」強化 Alien Reinforcement AR この内, 漢語と英語は学習者の立場から強化を記述して 抢り，和語法教授者の立場から強化を記述したものであ る。

春木（1978）に基うくく一連の実験研究では和語を用い てきた。しかし当論文では, Haruki, et al. (1978, 1980. 1984）等の英文の論文で用いられている英語・漢語の用 語を用いることにする。 
進められており（柏木, 1972, 1976 ; 福島, 1980a ; 佐 佐木・福島, 1979 ; 塩田, 1978, 1979 ; 石田, 1981 ; 根 建, 1978), 学習におよぼすその効果についてはさまざ まに議論されている。この強化は強化子が学習者側に管 理されているので, 行動の選択と決定は学習者自身にあ り, 環境から自律した行動の制御であるといえる。自律 的な人間では, 自分で決定し自分で評価するという行動 は日常行われていることである。(3)内的強化は, 強化子 の管理は学習者であり, 受理は教授者である場 合であ る。行動の選択は学習者にあり, その行動による結果を 教授者が受理するのである。たとえば, クライエントが 自発的に発言したり行動したりすることをカウンセラー が受容するという場合や，子供の行動を親がそのまま受 けとめたりする場合がこれにあたる。それによって，ク ライエントや子供の行動が強化されるという仮説であ る。このような強化のモードについての実験的研究はほ とんどなされていないが, Haruki et al: (1979)や井上 ほか（1983）によると特に, 新しい行動の変容をもたら すという結果は得られていない。これについては, 更に 今後の研究を必要とするであろう。最後に, (4)他者強化 である。これは強化子を教授者が管理し, 受理も教授者 自身というものである。標的行動の選択権は教授者側に あり，学習者は教授者の望んでいる行動をすることによ って教授者に満足を与えることができ，それが学習者の 行動を強化することがあるという仮説である。この強化 のモードの例をあげるとすれば，夫の望みの料理を作り 夫に喜んでもらうことが，妻の料理を作る行動を強化 し，学業でよい成績を取ることが母親を喜ばせるなら ば,こどもの勉学への動機ゔけは高まることなどがあげ られる。また,まわりから期待されたとおりの成績をお さめた選手は, コーチや応援団を喜ばせたことによっ て，更に練習へのはげみになるということがある。

以上述べて来た強化のモードは, 現実生活の中で単独 で機能することはあまりないかもしれない。上に述べた 例のように, 夫や母親や応援団が喜んだことだけが生じ ているのではなく，同時に妻やこどもや選手自身もその 行動を自らよしとして, その結果に満足しているであろ らし, 更にその行動に対して, 賞賛をあびるといらこと もおこる。このことは, 他者強化のみでなく, 自己強化 や外的強化が生じているということになる。このよう に, 現実生活の中では, 4 つの強化のモードは複合して おこっているのが自然であろら。従って 4 つの強化のモ ードを組合わせた強化の効果についての実験的研究が必 要であると考える（福島, 1980b)。

他者強化については, 春木他 (1976), Haruki, et al.
（1979）が，大学生の被験者について無意味経りの四肢 択一式弁別課題の学習において, 外的強化と同等の効果 をもつことを指摘して以来, 一連の研究で同様の結果が 得られている（例えば, 佐々木他, 1981)。他者強化と 外的強化の組合わせの効果については, 春木他 (1980), Haruki, et al. (1984) 以来検討されて来ているが, 今 までのところは, 組合わされることによる積極的な効果 は特に得られていない。しかし，この組合わせ強化が外 的強化よりも効果をもつのは, 協力課題の場面であると いうことが見出されている（小川他，1983）。

このように他者強化は行動制御あるいは学習に効果を 持つといらことがほぼ確実であるが，同時にさまざまな 要因によってその効果のあらわれ方が異なることも予想 される。例えば Haruki et al. (1980) では被験者に小 学校 3 年生と 6 年生を用い, 高さの弁別学習課題を他者 強化で学習させたところ, 小学生では概して外的強化ほ ど效果がないことが認められた。特に実験者の性によっ て，その効果が異なることが指摘された。これと同様の ことが, 実験者のパーソナリティとの関連についても指 摘されている（重久他，1981）。

そこで本実験では他者強化と他者強化・外的強化の組 合わせ強化について，その効果が年齡によって異なるか どうか, 外的強化との比較を通じて調べることとした。 学習者の年齢の範囲は, 大学生では効果があることがす でにわかっているので, 小学校 3 年から高校 2 年までと した。

\section{実 験 I \\ 目的}

他者強化 (AR) 及び外的強化・他者強化の組合わせ強 化 (EAR) が小学校 3 年生, 小学校 6 年生, 中学校 3 年 生において学習にどのような効果をもつか, 外的強化 (ER) との比較を通じて調べることを目的とした。

\section{方 法}

被験者 被験者は実験経験のない小学校 3 年生と 6 年 生, そして中学 3 年生の 3 学年, 各30名ずつ（男女半数 ずっ）計90名が学習者（L）として参加した。被験者は, すべてY大学付属小学校及び中学校の生徒であった。

実験者 心理学専攻の女子学部生 1 名が, 実験全体を 管理する実験者 $(\mathrm{E})$ として参加した。また, 心理学専攻 の学部生10名（男女 5 名ずつ）が教授者（T）の役割をと る実験補助者として参加した。

群構成 各学年 30 名の Ls を外的強化群 (ER群), 他 者強化群 (AR群), 外的 -他者強化群 (EAR群) の 3 つ の強化条件群に10名ずつランダムに割り当てた。10名の Ts の群への割り当ては各学年において全ての強化条件 
を施行するように調整された。

刺激材料 弁別刺激は, 形・色・高さの 3 つの次元で, それぞれ 3 通りの值をとる 27 種類の 紙製の積み木。形 は, 円柱・四角柱 -三角柱の 3 通り。色は, 白・青 - 赤 の 3 通り。高さは $2 \mathrm{~cm} \cdot 4 \mathrm{~cm} \cdot 6 \mathrm{~cm} の 3$ 通りであった。強 化子は, 0 点から 100 点まで, 2 点刻みに点数が書かれ た51枚の得点カードを用いた。

課題 27 種類の積み木の中から, 形・色・高さの 3 つ の次元の值が全て異なる 2 つ積み木を組合わせた対を 10組用意して, 被験者に対提示し, 一方を選択させた。 正解の手掛かり（関連次元）は, 積み木の高さであっ た。高低いずれが正解となるかは，ランダムに決められ た。課題の困難度は, 学年によって異なっていた。小学 校 3 年生（以下 P 3 ） では, 色と高さを 2 通り（赫と白; $6 \mathrm{~cm}$ と $2 \mathrm{~cm})$ に制限し， $2 \times 2 \times 3$ の 12 種類の中から刺激を 選んだ。小学校 6 年生（以下 P 6 ） では，高さを 2 通り に制限し， $2 \times 3 \times 3$ の 18 種類の穦み木から刺激を作成し た。中学 3 年生（以下 J 3) では, このような制限は設 けなかった。このためP3とP6では, 高さの絶対弁別が 課題となり，J3では，相対弁別が課題となった。この 困難度の調整は, 学年によって認知的能力が異なるため に生じる成績の差を考慮して行われたものであった。こ の調整による影響は, 結果および考察の項で検討する。

手続 $\mathrm{E}$ は, 予め Ts 各強化条件における強化子操 作と教示が正確に行えるように訓練した。Tsには, 強 化子の操作方法と教示の与え方だけを教え, 実験の仮説 や目的については, 同意の上, 実験終了まで知らせなか った。実験は, 学年別に 3 日に分けて行われた。普通の 教室 3 つを, 控え室及び実験室として使用した。Ls は, 控え室に集められ，Ts は 2 つ部屋に半数ずつ別れて 待機した。2つの実験室には, 向かい合わせに置かれた 2 つの机とその両側に置かれた 2 つの椅子が，それぞれ 5 組ずつ, 適当に距離をおいて配置されており, Ts は 1 人ずっ別の机に座っていた。実験が始まると, Lは順 番に控え室から $\mathrm{E} に$ 伴われて実験室に行き， $\mathrm{T}$ の前に座 るように指示された。 $\mathrm{T}$ は, Lに教示を与え, 学習効力 感 1 (L E 1) の測定を行ってから, 再度教示を与えた。 Lからの質問に対しては, 教示の一部または, 全部を繰 り返した。教示後, 学習試行に入った。Tは, Lに刺激 対（2 個の積み木）を提示して, Lの選んだ積み木が正 しいものならば, 得点カードをめくり得点を 2 点加え た。10試行 1 ブロックとし, 最高 6 ブロックまで行っ た。1ブロック $100 \%$ 正答の場合は, 学習が完了したもの として終了した。途中で学習が完了したLについては, 完了後は全問正答したものとして扱った。学習試行終了
後, 学習効力感 $2(\mathrm{~L} \mathrm{E} 2)$ と強化子の報酬価（R V) の 測定を行った。ここで実験は終了し，Tは L を送り出し

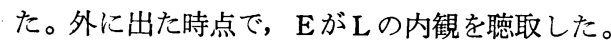

教示 教示は強化条件毎に異なるものであった。各強 化条件に共通した教示は, 次のようであった。

「これからテストをします。このテストは，一生懸命 やれば誰にでもできるものです。それでは，これから 2 つの積み木をあなたの前に置いて見せます。あなたは, 2 つのうちどちらか 1 つを選んで, 持ち上げてくださ い。」この教示に続いて，強化条件によって異なる教示 が与えられた。

E R 群 「あなたの選び方によって，私があなたに点 数をあげます。ですから，あなたはできるだけ早く，で きるだけ沢山，点数を集めてください。」

A R 群「あなたの選び方によって，私は点数をもら うことができます。ですから，私はできるだけ早く，で きるだけ沢山，点数を集めたいのです。」

EAR 群「あなたの選び方によって，私があなたに 点数をあげます。そして，また私も同じだけ点数をもら らことができます。ですから，あなたはできるだけ早 く，できるだけ沢山，点数を集めてください。私もでき るだけ早く，できるだけ沢山，点数を集めたいのです。」 学習効力感 (L E) : E R 群では,「あなたは，どのく らい点数を取ることができると思いますか？」という問 いに対して，「ぜんぜんとれない」から「とてもたくさ んとれる」までの 9 段階で評定させた。A R 群では, 「どのくらい取らせることができるか？」について，

EAR 群では，この両方について，9段階で評定させた。 また, 学習終了後の 2 回目の測定 (L E 2) では,「もう 1 度今やったのと同じようなことをするとしたら」とい ら条件で 1 回目と同じ質問に答えさせた。

強化子の報酬価(R V) 「あなたは，こんなに点数を 取ることができて（取らせることができて）, どれくら い嬉しい?」という質問に 9 段階評定で答えさせた。

内観報告「正解が分かったか？」・「正解の分かった 問題では，必ず正しい積み木を取ったか？ 取らなかっ たならば，それはどうしてか?」・「実験者（ここではT のこと）を好きか嫌いか？」の 3 点について質問した。

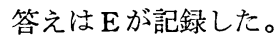

\section{結果}

課題が学年毎に異なるので, まず学年毎に強化条件を 比較し, 学年間の比較は強化条件毎に行った。

〈学年毎の強化の効果の比較〉

小学校 3 年生 (P3) P3の成績を強化条件別に示した のが FIG. 1(a) である。EAR と ER に比べて, AR 


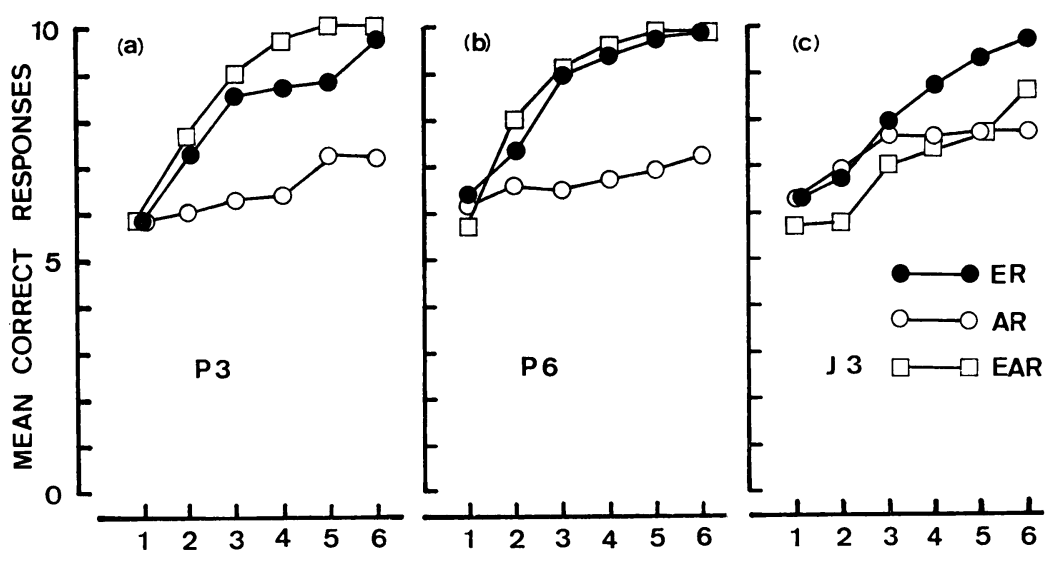

B L $\quad$ O $\quad$ C $\quad K \quad S$

FIG. 1 1. Mean correct responses for each reinforcement condition in each grade as a function of the block (one block contained 10 trials). - (a) 3rd graders of primary school. (b) 6th graders of primary school. (c) 3rd graders of junior high school.

の成績が劣っているのがわかる。強化条件(3)×ブロック (6)の分散分析の結果, 強化条件とブロックの交互作用 （ $\mathrm{F}=2.31, \mathrm{df}=10,135, \mathrm{p}<.05 ）$ が有意であり，強化条 件の主効果は, 有意な傾向を示した $(\mathrm{F}=2.56, \mathrm{df}=2,27$, $\mathrm{p}<.10)$ 。被験者の個人差 $(\mathrm{F}=24.95, \mathrm{df}=5,135, \mathrm{p}<$ .01）とブロックの効果（ $\mathrm{F}=24.95, \mathrm{df}=5,135, \mathrm{p}<.01)$ も有意であった。また，第 1 ブロックと最終ブロックの 成績を条件別に $\mathrm{t}$ 一検定で比較したところ, $\mathrm{ER}(\mathrm{t}=9.49$, $\mathrm{df}=9, \mathrm{p}<.001)$ と EAR $(\mathrm{t}=11.70, \mathrm{df}=9, \mathrm{p}<.001)$ で は，成績の有意な上昇が認められたが，A Rでは，認め られなかった。この結果は, 弁別課題における A R 単独の 効果が P3では認められないことを示しており, Haruki, et al. (1980) のP3 の結果と一致する。

小学校 6 年生 (P6) P6の成績を強化条件別に示すと FIG. 1 (b) のようになる。P3よりも，EAR と ER の 差が小さくなっている他は，P3 と同様の結果が読み取 れる。分散分析の結果, 強化条件とブロックの交互作用 が有意であり $(\mathrm{F}=2.30, \mathrm{df}=10,135, \mathrm{p}<.01)$, 強化条 件の主効果は，有意な傾向を持っていた（ $F=2.70, \mathrm{df}$ $=2,27, \mathrm{p}<.10)$ 。個人差 $(\mathrm{F}=16.92, \mathrm{df}=27,135, \mathrm{p}<$ .01）およびブロックの効果（ $\mathrm{F}=23.01, \mathrm{df}=5,135, \mathrm{p}<$ .01）も有意であった。ER（ $\mathrm{t}=4.26, \mathrm{df}=9, \mathrm{p}<.01)$ と $\operatorname{EAR}(\mathrm{t}=10.82, \mathrm{df}=9, \mathrm{p}<.001)$ では，有意な成績の上 昇が見られたが，A R条件のみ成績の上昇が有意でなか った。この結果も Haruki, et al. (1980) のP6の結果と 一致する。

中学校 3 年生 (J 3) FIG. 1 (c) に J 3の強化条件 別の
成績を示す。P 3・P6 とは異なる 傾向が読み取れる。 $\mathrm{P} 3 \cdot \mathrm{P} 6$ では, EAR $\geqq \mathrm{ER}>\mathrm{AR}$ であったのに対し，J3 では, EAR が ER と AR の中間に位置している。分散 分析の結果, 個人差 $(\mathrm{F}=13.45, \mathrm{df}=27,135, \mathrm{p}<.01)$ と ブロックの効果（ $\mathrm{F}=12.96, \mathrm{df}=5,135, \mathrm{p}<.01)$ だけが 有意であり, 強化条件の主効果及びブロックとの交互作 用は，有意でなかった。 $\mathrm{t}$ 一検定の結果では, ER と EAR の成績は有意に上昇し $(t=5.50, d f=9, p<.001 ; t=$ 4. $66, \mathrm{df}=9, \mathrm{p}<.001), \mathrm{AR}$ では成績の上昇は認められな かった。

\section{〈学年の比較〉}

課題が学年毎に異なるので, 学年の要因を含めて分析 することはできない。ここでは各強化条件毎に学年間の 比較を行い，学年の効果に関する推論を行う。

平均総正反応数を強化条件別に（P3，P6，J3）の 形式で示すと, ERで $(48.3,51.3,48.7)$, A R で(38.8, 39.6, 43.8), $\operatorname{EAR}$ で $(52.1,51.7,42.2)$ であった。強 化条件別の分散分析の結果, ER と A R では学年差が見 られず，EAR では J3の成績が P 3やP 6の成績よりも有 意に劣っていることが示された（F=4.02, $\mathrm{df}=2,27, \mathrm{p}$ $<.05$; Tukey, $\mathrm{p}<.01)$ 。

E Rで学年間に成績の差が生じなかったことは, 課題 の困難度の調整がうまくいっており，学年間の成績の比 較がある程度まで意味を持つことを示すものである。

〈個人差の分析〉

個人差のあり方を分析するために，クラスター分析を 行った。90名の学習曲線を分類したことろ，7つのクラ 
TABLE 1 Numbers of subjects for each group classified into each cluster and mean scores of Learning-Efficacy and Reinfocer's Value

\begin{tabular}{|c|c|c|c|c|c|c|c|c|c|c|c|}
\hline \multirow[t]{2}{*}{ Grade } & \multicolumn{3}{|c|}{ Reinforcement } & \multicolumn{4}{|c|}{ Cluster } & \multirow{2}{*}{\multicolumn{2}{|c|}{$\begin{array}{c}\text { LE1 } \\
\text { VII (Pre-) }\end{array}$}} & \multirow{2}{*}{$\begin{array}{l}\text { LE2 } \\
\text { (Post- }\end{array}$} & \multirow{2}{*}{$\begin{array}{l}\mathrm{RV} \\
-)\end{array}$} \\
\hline & condition & I & II & III & N & V & V & & & & \\
\hline \multirow[t]{3}{*}{$\mathrm{P} 3$} & E R & 5 & 2 & & 1 & 2 & & & 5.1 & 6.4 & 7.4 \\
\hline & AR & 4 & 1 & & 1 & 2 & & 2 & 5.3 & 6.2 & 6.2 \\
\hline & $\mathrm{EA}$ & 5 & 5 & & & & & & 5.1 & 7.5 & 7.4 \\
\hline \multirow[t]{3}{*}{$\mathrm{P} 6$} & E R & 3 & 6 & & 1 & & & & 4.4 & 6.9 & 7.4 \\
\hline & AR & 5 & 1 & & & 1 & 1 & 2 & 4.7 & 5.6 & 6.0 \\
\hline & E A & 6 & 3 & & 1 & & & & 5.4 & 7.0 & 5.6 \\
\hline \multirow[t]{3}{*}{$\mathrm{J} 3$} & E R & 3 & 4 & 1 & 2 & & & & 4.8 & 7.3 & 3.9 \\
\hline & A R & 5 & & 1 & 1 & 1 & 1 & 1 & 5.6 & 7.3 & 5.3 \\
\hline & EAR & 2 & 3 & 1 & 1 & 1 & 2 & & 4.7 & 5.9 & 4.5 \\
\hline
\end{tabular}

スターに分類された。I（以下，クラスター番号をロー マ数字で表わす）は, 学習の最も速い群である。II は, I より 1 ブロック程遅れて学習が成立する群である。 III は，1度成績が下降した後，一転して上昇し，II と同時 期に学習が成立する群である。N は, 正答数が的 7 で安 定する群。Vは, 成績の伸びが遅く， 7 ぐらいまでしか 伸びない群。VIは, ランダムに反応している学習不成立 群。VIは，急速に成績が下降して正答数 0 になる群であ る。I・II ・ III は学習成立群。N・Vは未完成群。V U 学習不成立群。VII は学習拒否群であると考えられる。VII の Ls は, 刺激対のどちらが正解か知っていながら, 故 意に逆の積み木を選択していたのである。各クラスター に入る Ls の人数を, 条件群別に集計した数值を TABLE 1 に示す。VIIの拒否者は，A Rのみに現われるのがわか る。また, $\mathrm{N} ・ \mathrm{~V} ・ \mathrm{~V}$ に含まれる人数に注目すると, A $\mathrm{R}$ と他の 2 つの群の間に差がない。このことは, 各学年 において A Rの成績がERやE A R よりも劣っていたの は拒否者が居たためであることを示している。 P3・P 6.J3の各学年の強化条件間の比較を拒否者を除いて行 うと, 各学年共に強化条件差が見られず, 強化条件とブ ロックの交互作用も有意でなかった。

〈学習効力感 $(\mathrm{L} \mathrm{E})\rangle$

分析の結果, 強化条件および学年の効果は認められな かった。ARも E R P E A R と同等に効力感を高める効 果を持っている（TABLE 1)。

$\langle$ 強化価 $(\mathrm{R} V)\rangle$

学年間に有意差が認められ（ $\mathrm{F}=13.89, \mathrm{df}=2,81, \mathrm{p}<$ $.01)$, 強化条件と学年の交互作用が認められた（F= $2.50, \mathrm{df}=4,81, \mathrm{p}<.05)$ 。群別の $\mathrm{R} \mathrm{V}$ の平均值を TABLE 1 に示した。多重比較の結果, P 3 と $\mathrm{P} 6$ の評定值が J 3 よりも高く（Tukey, p<.01）なっているのがわかった。
また，交互作用は，P3・P6で評価の高かった E Rが J3で低く，AR は学年による差がなく，EARは P3，P6，J3 と徐々に低下するというように，学年毎 に強化のモードの効果が異なることを示していた。

〈被験者の内観〉

学習試行後に実験者が質問によって集めた内観のデー クの内で, 考虑すべき項目は次の 2 点であった。(1)正解 の理解度。質問を受けた時点で正しい選抧基準を学習し ていた被験者の数上学習完成者の数の差（正解を知って いながら故意に䛊反応したと思われる者の数）と，クラ スター分析で拒否者として分類された者の数を比較する と, 後者以外にも選択基準を学習していながら故意に誤 反応をしていた者がおり（P6のARで 1 人，J3のAR で 2 人)，AR条件に集中している事が明らかとなった。 (2)補助者に対する印象を「好き」か「嫌い」かで答えさ せたところ，「好き」と答えた人数が「嫌い」と答えた 人数よりも有意に多かったのは, P3 の E R（10人中 9 人）と 3 つの強化条件を合計した場合のP 3 （30人中 25 人）亡 $\mathrm{P} 6$ ( 30 人中 22 人) であった。有意ではなかった が，J 3 全体では「嫌い」と答えた人のほうが多く（13 対17)，ARのみで「好き」と答えた人が多くなってい た $(7$ 対 3$)$ 。

\section{考察}

結果から明らかに, ERはどの学年においても安定し た効果を持つ。それに対してARは，どの学年において も有意な成績の上昇が見られなかった。しかしこのよ うなARの効果の低さは, 故意に誤反応する拒否者がい たためであり, 拒否者を除いた場合の成績では, A R は E R と同等の効果を持っていることが示された。また, 動機づけに関連すると思われる L E P R V 等の指標では 差が見られず, さらに内観において，J3ではARがむ しろプラスに働いて，Tに対するLの評価を高めている ことが注目される。E A R は, P3・P6では, ほとんど 同一の効果を示し, P3 では E Rよりもむしら成績が良 いが，J3では成績の低下が見られた。この現象の原因に ついては, 明確な結論を下寸積極的な証拠がないが, 課 題の特性と被験者の年齢（思春期にあたっている）が関 係していると思われる。

総合すると, ARでは, 小学生から中学生の段階では 学習成績の有意な上昇が生起しない。これは故意に正答 を回避し誤反応を繰り返す拒否者の存在が学習完成者の 成績を相殺してしまうためであった。ERとEARとは 似通った傾向を示すが, E A R が J 3 で成績の低下を示 すところから，ERの方がより安定した効果を示すと言 える。 


\section{実 験 II \\ 目 的}

実験 Iでは, 小学生から中学生までの被験者に対する 2 つの強化のモード，すなわちER の 2 つの強化モードを同時に随伴させる 2 重強化（E A R）の効果を比較した。実験 II では，さらに年齡の高い 高校生の被験者を用いて, 実験 I で比較した 3 つの強化 条件を比較する。また, 実験 I で得られた中学生のデー 夕を再確認するために中学生を被験者とする群も設け た。課題は, Haruki, et al. (1979) で用いたものと同 様の, 単語の弁別記憶学習課題を用いた。実験 I では学 年毎に課題の内容が異なっていたために直接学年の効果 を検証することが出来なかった。そこで実験 II では, 中 学生と高校生に同一の課題を用いて比較した。

\section{方 法}

被験者 都内の公立 $\mathrm{K}$ 中学校の 2 年生, 及び公立 $\mathrm{T}$ 高 等学校の 2 年生の生徒 72 名が被験者 (学習者; L) とし て実験に参加した。各学年36名ずっで, 男女同数であっ た。

実験者 心理学専攻の 学部学生延べ 24 名が, 教授者 （T）の役割をとる実験補助者として参加した。各学年に 対して，12名ずっ（男女6名ずつ）のTが参加した。実 験者 (E) は, 心理学専攻の女子学部生 1 名であり, 実 験全体の進行を管理した。Tには, 実験の結果に影響を 与えぬように, 実験のやり方のみを訓練し, 実験の仮説 や目的については知らされていなかった。

群構成 各学年毎に, ER・AR・EARの 3 つの強 化条件群を設け, 男女 6 名ずつの被験者をランダムに割 り当てた。Tは, どの強化条件も必ず 1 度は施行するよ らに調整された。どのLがどのTと組合わされるかは, TとLの性の組合わせがうまくいくように調整された が，その範囲内でランダムに決められた。

刺激材料 $6 \mathrm{~cm} \times 7.5 \mathrm{~cm}$ のカードに, カタカナで縦書き に4つの単語を並べたリストを印刷したものを用いた。 単語の組合わせは 8 種類あり, 単語の並び方をそれぞれ 4 通りに入れ替えて, 計 32 枚のカードを 12 組用意した。 8 種類のリスト内の単語は全て異なり, 同一リスト内の 4 つの単語は文字数や濁音の有無が揃うように選ばれ た。またリスト内の 4 つの単語は，それぞれ「道具」・ 「動物」「「自然現象」・「植物」の 4 つのカテゴリーから 選ばれたものであった。強化刺激は, 直径 $26 \mathrm{~mm}$, 重さ $7 \mathrm{~g}$ の銀色の金属製コインを用いた。

課題 刺激リストの 4 つの単語の中から, 正解と決め られている単語を選択する弁別学習課題。

手続 実験は個人実験で行った。実験室の設置および
Tの配置は実験 I と同様にした。Lは, 実験者に伴われ て実験室に行き， Tと向かい合って座った。TはLに対 して教示を与えた後, 実験 I と同様の方法で学習効力感 1 （L E 1）を測定し, 教示を再度繰返した。次に学習 試行に入り，Tは決められた順序でカードを呈示し， L に単語を 1 つ選択させた。この時 Lの選択が正しけれ ば，Tは強化子の操作を行った。8 試行を1ブロックと して，10ブロックまで行った。途中で 2 ブロック連続し て100\%正解になった場合は, 学習が成立したものとし て学習試行を打ち切った。試行後, Tは $\mathrm{L}$ の学習効力感 2 （L E 2） と強化価（R V) の測定を行って，Lを控 え室に戻した。Eは, 控え室でLに内観を筆記式で回答 させた。

教示 教示は強化条件毎に異なるものであった。全て の強化条件に共通の教示は次のようであった。

「これから簡単なゲームをします。私があなたの前に カードを見せます。それにはカタカナで 4 つの単語が書 いてあります。(練習用カードを示して)この様にです。

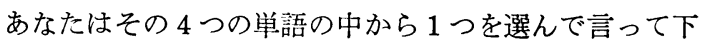
さい。」(練習用のカードの中には, 学習試行用の単語は 含まれていない。）この教示に続いて，実験 I と同様の 強化条件別の教示が与えられた。

学習効力感・強化洒 実験 I と同様に, 9 段階評定尺 度で測定した。

結 果

実験 II では，両学年を通して課題が一定であったの で, 学年の要因を含めた分析が可能である。そこで, 学 年の効果に関する分析を先に行い, 学年毎の強化条件の

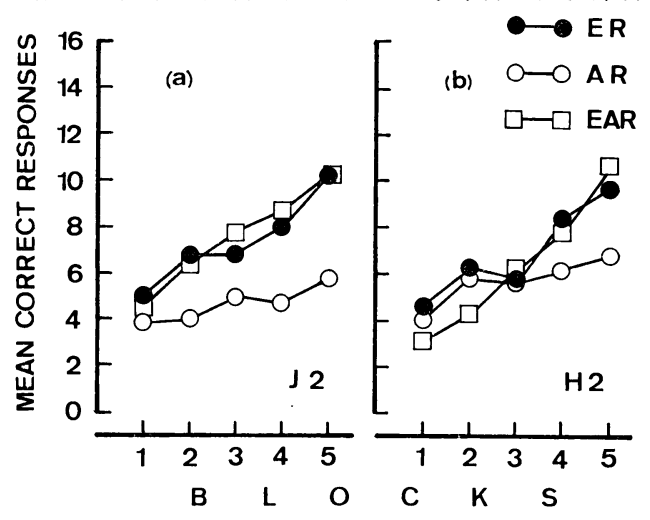

FIG. 2 Mean correct responses for each reinforcement condition in each grade as a function of the block (one block contained 16 trials). - (a) 2nd graders of junior high school. (b) 2nd graders of senior high school. 
効果の比較をその後で行うことにする。 〈学年の比較〉

中学 2 年生 $(\mathrm{J} 2)$ と高校 2 年生 (H2) における各強 化条件の成績を, ブロック毎にまとめたのがFIG. 2 であ る。学年 $\times$ 強化条件 $\times$ ブロックの分散分析の結果, 強化 条件の主効果 $(\mathrm{F}=3.32, \mathrm{df}=2,66, \mathrm{p}<.01)$ が有意であ った。また, ブロックの主効果（ $\mathrm{F}=33.98, \mathrm{df}=9,594$, $\mathrm{p}<.01)$, 強化条件とブロックの交互作用 $(\mathrm{F}=3.01, \mathrm{df}$ $=18,594, \mathrm{p}<.01 ）$ が有意であり，個人差も認められた $(\mathrm{F}=12.21, \mathrm{df}=66,594, \mathrm{p}<.01)$ 。第 1 ブロックの成績 については強化条件間に有意差が認められなかった。こ れは，強化条件によって成績の上昇に差があることを示 している。多重比較の結果 E R と A R がA Rよりも優 れていることが示された (Tukey, $\mathrm{p}<.05$ )。学年の主効 果および学年汇関する交互作用は有意でなかった。

〈各学年における強化の效果の比較〉

$\mathrm{J} 2$ 実験 I の結果上同栐に, A R の成績が上昇せず, ERやEARよりも劣っており，ER と E ARの間に は, 差が見られないのがわかる。分散分析の結果, 強化 条件の主効果汕有意な傾向を示し $(\mathrm{F}=2.95, \mathrm{df}=2,33$, $\mathrm{p}<.10)$, 強化条件とブロックとの交互作用は有意でな かった。ブロックの主効果 $(\mathrm{F}=13.00, \mathrm{df}=9,297, \mathrm{p}<$ .01）と個人差（ $\mathrm{F}=14.12, \mathrm{df}=33,297, \mathrm{p}<.01 ）$ は共に 大きく有意であった。第 1 ブロックと最終ブロックの成 績を比較したところ，E Rと E A R で有意な成績の上昇 が認められた（ $\mathrm{t}=4.52, \mathrm{p}<.01 ; \mathrm{t}=6.00, \mathrm{p}<.01 ; \mathrm{df}=$ 11)。A R では，成績の有意な上昇が認められなかった。

$\mathrm{H} 2 \mathrm{~J} 2$ に比べてARの上昇が大きくなっている。強 化条件の主効果は認められず, 強化条件とブロックの交 互作用が有意であった（ $\mathrm{F}=2.56, \mathrm{df}=18,297, \mathrm{p}<.01)$ 。 ブロック（ $\mathrm{F}=9.89, \mathrm{df}=33,297, \mathrm{p}<.01)$ と個人差（ $\mathrm{F}$ $=9.89, \mathrm{df}=33,297, \mathrm{p}<.01)$ の要因は共に有意であっ た。また，各強化条件共に有意な成續の上显を示した $(\mathrm{t}=3.88, \mathrm{p}<.01 ; \mathrm{t}=2.83, \mathrm{p}<.05 ; \mathrm{t}=9.80, \mathrm{p}<.01 ;$ $\mathrm{df}=11)$ 。第 1 ブロックと第 10 ブロックの成績の差索強 化条件間で比較したところ，ARと E A Rの間に有意な 差が認められた（Tukey, $\mathrm{p}<.05) 。$

〈個人差の分析〉

クラスター分析の結果，5つのクラスターが得られ た。Iは学習の速い群, II は後半に成績の上昇する群, III は正答数が 5 程度までしか上昇しない群，N $\mathrm{N}$ は学習不 成立の群, Vは拒否者の群がある。V を拒否者としたの は, このクラスターに入る Ls の正答数を見ると, 最終 3 ブロックの正答数がほぼ 0 であり, 四肢択一課題でこ のような成績になる確率が $1 \%$ 以下であるためである。
各クラスターに含まれる人数を条件群別に集計した結果 が, TABLE 2 である。拒否者はJ2のARのみで現われ た。ただし，実験 Iのような成績の両極化は見られず， 全体的に成績が悪い。学年間の傾向の比較を行うと,

TABLE 2 Numbers of subjects for each group classified into each cluster and mean scores of Learning-Efficacys and Reinfocer's Value

\begin{tabular}{clllllllll}
\hline $\begin{array}{c}\text { Grade Reinforcement } \\
\text { condition }\end{array}$ & I & II & II & N & V & (Pre-) & (Post-) \\
\hline J2 & E R & 3 & 3 & & 6 & & 4.0 & 6.2 & 4.3 \\
& A R & & 4 & & 4 & 4 & 5.6 & 6.2 & 5.3 \\
& E A R & 3 & 3 & & 6 & & 4.3 & 6.6 & 4.3 \\
H2 & E R & 3 & 2 & 4 & 3 & & 4.4 & 6.3 & 3.5 \\
& A R & 1 & & 5 & 6 & & 5.5 & 5.5 & 3.4 \\
& E AR & & 4 & 7 & 1 & & 5.2 & 6.3 & 3.7 \\
\hline
\end{tabular}

J2ではERとEARの人数の分布が等しいのに対し， $\mathrm{H} 2$ では E R の汪らが成績の良いものが多く E A R 中 程度の成績の者が多くなっている。

〈学習効力感 $(\mathrm{L} \mathrm{E})\rangle$

分散分析の結果, 学習前後の差 $(\mathrm{F}=24.36, \mathrm{df}=1,66, \mathrm{p}$ <.01）が有意であり, 強化条件と学習前後の差の交互 作用が有意な倾向を示した（ $\mathrm{F}=3.01, \mathrm{df}=2,66, \mathrm{p}<$ .10)。これは, TABLE 2 に示したLEの平均を見ると分 かるように, ARのLE1が他の 2 群より高く L E 2では 差がないことが原因である。

〈強化価 $(\mathrm{R} V)$ 〉

結果を, TABLE 2 に示す。分析の結果, 学年の主効果 が有意であり $(\mathrm{F}=7.05, \mathrm{df}=1,66, \mathrm{p}<.01), \mathrm{J} 2$ が $\mathrm{H} 2$ よりも強化価を高く評定したことを示している。

\section{考察}

学年每の強化条件の比較において, J 2 ではARの学 習に対する効果が有意でなかった。 H2では，AR注成 績の上昇が E A R よりも劣るものの, A R による成績の 上昇が有意であり， E R との差が認められなかった。こ れは，学年の上昇と共に A R の効果が増大することを示 すものである。また， $\mathrm{H} 2$ において拒否者が見られなか ったこともこのことを裹付けている。しかし，学年×強 化条件 $\times$ ブロックの分散分析で学年の効果が認められな かったこと, 強化条件とブロックの交互作用が有意であ ってARの効果が E R E A Rよりも劣っていたこと は，これを肯定しない結果である。このような結果は非 常に微妙であり,ここでは結論が下せない。しかし， Haruki, et al. (1979) で大学生のA Rの成績が E Rのそ れよりも勝っていたことと考え合わせると，ARは高校 
生から大学生にかけての時期になって初めて有効になる と考えられる。

\section{総合考察}

\section{〈課題の差の問題〉}

実験 I では, P3・P6・J 3の各学年に対して 困難度 の異なる課題を与え, 学年間の学習能力の違いを相殺し ようとした。これに対して，実験 II では，学年間の直接 の比較を行えるように課題を同一のものとした。しか し, 実験 I の課題は 2 肢択一の高さの弁別学習であり, 実験 II の課題は単語の 4 肢択一の選択学習（弁別学習） であった。この課題の困難度と課題の質の差は平均正答 数（成績）にはっきりと表われている。達成率（最終ブ ロックの正答数/1ブロックあたりの試行数）を見ると， 実験 I の J 3-ERで.97, 実験 II の J 2-E R で.46で あった。1 試行毎に正答の得られる確率（実験 I で $1 / 2$, 実験 II で1/4）を考えると，この差はほぼ相殺されるが, 直接の比較は難しい。これは, 今後学年間の比較を行う 上での大きな問題である。

〈ARの成績の学年による変化〉

実験 I では，各学年毎にE R・A R・E A Rの 3 つの 強化条件の効果を比較した。実験 II では，2つの学年で 強化条件の効果を比較した。E R は学年や課題によって 生じる変動が最も少なかった。実験 I では各学年共に学 習者の $80 \%$ 以上が学習を完了しており, 全員が $80 \%$ 以上 の正答率を達成している。実験 IIでも J 2 ・H2 ともに約 半数の者が学習完了しており，EA Rと比較してほぼ同 等の成績となっている。これに対して, A Rは, 実験 I の 3 つの学年でそれぞれ $60 \%$ の者が学習を完了してお り，実験 II では学習完了者が12名中 2 名のみであった。

この結果は, 実験 I と II の課題の困難度の差を考虑に 入れると，A Rが課題の困難度の上昇に対して弱い側面 を持っていることを示している。しかし，A Rの成績の 有意な上昇を妨げて来た拒否者は，実験 II の H 2 におい て初めていなくなり， H2では A Rの平均正答数の有意 な上昇が認められた。この結果と, Haruki, et al. (1979) の結果とから総合的に判断すると, A Rの効果は, 高校 生から大学生にかけての時期に優勢になるものと考えら れる。

A Rの効果がこのように年齢によって異なる事実は, $\mathrm{E} R$ Rがどの年齡においても同等の効果を持つことと比較 して興味深い。しかし，これが何故かという理由につい ては,ここでは特に触れないことにする。なぜなら，こ のことについて論じる前に問題とすべきことが多くある からである。ここで強化子に得点やコインが使われたが これを金銭にした場合には結果が異なるかもしれない。
A Rの効果の意味は，様々な要因の影響によって変動す る可能性を持っていると考えられる。

〈EA Rの効果〉

実験 I において，P3・P6でのE A Rの効果は強力で あり，E Rと同等あるいは，それ以上の正答数を引き出 している。これに対して，実験 I の J 3 では，EARの 成績が， E Rのそれに比べて低下が著しく，P3・P6の E A Rとの間に有意な差が認められた。実験 II では，J 2・H2共にE A RはE R と同等の効果を持ち, 実験 I の J3で見られたようなEA Rの効果の低下は見られなか った。J 3 と，ほぼ同年齢の J 2でE A Rの効果の低下が 認められず， H2 でもE A Rの低下は見られていないこ とから, 実験 I の J 3の結果は, 中学 3 年生という学習 者の年齢等の原因によって生起したものと考えられる が, 今後の研究を待たなくてはならない問題である。

実験 Iの J 3 を除けば, E A Rの効果はERのそれと 何等変わるところがなく， A Rを E R と同時に随伴され た効果は，ほとんど認められなかったと言える。しか し, 現在進行中の研究結果では, E A R2 重強化の有効 性は, 教授者と学習者が協力して学習者の学習を推し進 めようとする協力場面で最むよく現われることが示され ている (小川他, 1983)。

\section{まとめと展望}

本研究では, 外的強化と他者強化を, 実験的操作的に 定義し， 2 重強化の効果と併せて検討した。被験者は， 実験 I では小学校 3 年生・ 6 年生と中学校 3 年生各 30 名 であり, 実験 II では中学校 2 年生と高校 2 年生各 36 名で あった。課題は, 実験 I では 2 者択一の高さの弁別学習 であり，実験【では 4 者択一の単語の弁別記憶学習であ った。実験の結果，A Rの効果については，学年が高校 生から大学生にかけての時期に有効となることが示され た。EARの効果については，ERとほぼ同様の効果が 認められた。

今回の研究では, 学年閒や実験間で課題が統一されて いなかったため, 結果を直接比較できなかった。被験者 の年齢に関係なく使用できる課題を用いた研究が期待さ れる。また，ARをE R と同一の土俵で比較するこれま での立場に加え，AR や E R の特性を引き出すような 状況を作り出す方向での研究が必要である。

\section{参考文献}

福島脩美 $1980 \mathrm{a}$ 「自己強化」の強化機能をめぐる理 論的検討 東京学芸大学紀要第 1 部門, 31, 321-327. 福島脩美 $1980 \mathrm{~b}$ 課題解決行動における自己強化と外 的強化の結合 日本教育心理学会第22回総会発表論 
文集, 82-83.

春木 豊 1978 制御行動の理論 一教育と治療の基礎 としての行動理論一 早稲田大学大学院文学研究科 紀要, 24, 1-15.

春木豊 ・ 伊藤秀子 ・ 大上良隆 $\cdot$ 近藤順子 $\cdot$ 川崎恵里子

1976 「あたえ」強化に関する実験的研究 (I ) 日 本心理学会第40回大会発表論文集, 475-476.

Haruki, Y., Ito, H., Oue, Y.,and Nedate, K. 1979 Four types of reinforcement process in humans. Psychological Reports, 45, 955-962.

Haruki, Y., Nedate, K., and Wajima, M. 1980 Effectiveness of alien reinforcement in facilitating learning in children, in relation to age and sex. Japanese Psychological Research, 22, 119-124.

春木 豊・根建金男 - 和島摩里 - 重久 剛 1980 「み とめ」強化阔関する実験的研究 (I) 一「おしつけ」 強化との関連に抢ける解析を中心として一 日本心 理学会第44回大会発表論文集, 297.

Haruki, Y., Shigehisa, T., Nedate, K., Wajima, M., and Ogawa, R. 1984 Effects of alien-reinforcement and its combined type on learning behavior and efficacy in relation to personality. International Journal of Psychology, 19, 527-545.

井上 聡・佐々木和義・春木 豊 1983 「まかせ・う けとめ」強化に関する実験的研究 (II) 一実験者効 果の検討一 日本心理学会第47回大会発表論文集, 356.
石田勢津子 1981 自己強化および自己評価の学習に及 ぼす効果 一正反応情報を伴う課題を用いて一 心 理学研究, 52, 274-280.

柏木恵子 1972 幼児の弁別学習における自己強化 (self-reinforcement) の機能 心理学研究, 42, 321-327.

柏木恵子 1976 人間学習に㧍ける自己強化 一その形 成機制と機能一 教育心理学研究, 24, 195-202.

根建金男 1978 自己強化の機能 心理学評論, 21, 264280.

佐々木和義 - 重久 剛 - 根建金男 - 和島摩里 - 春木 豊 1981 「おしつけ・みとめ」強化汇関する実験的研 究 一制御者が人間の場合上機械の場合の比較一 日本心理学会第45回大会発表論文集, 253.

佐々木正人, 福島脩美 1979 自己強化手続きによる自 己評価基準の形成と正反応の増大 心理学研究, 50, 43-51.

重久 剛・根建金男 - 和島摩里・春木 豊 1981 「み とめ」強化に関する実験的研究 (U) 一実験者と 被験者のパーソナリティの交互作用一 日本教育心 理学会第23回総会発表論文集, 736-737.

塩田勢津子 1978 自己強化の機能に関する実験的研究 教育心理学研究, 26, 162-171.

塩田勢津子 1979 自己強化敒関する研究の動向 名古 屋大学教育学部紀要 一教育心理学科一, 26, 103116.

(1984年12月 4 日受稿) 